\title{
Isolation of flavonoid from Abies webbiana leaves and its activity
}

\author{
Dinesh Kumar Yadav ${ }^{1 *}$, Mohammed Ali², Ashoke Kumar Ghosh ${ }^{3}$, Babita Kumar ${ }^{1}$ \\ 'College of Pharmacy, Shree Ganpati Institute of Technology, Ghaziabad (U.P.), INDIA. \\ 2Pharmacognosy \& Phytochemistry, Phytochemistry Research Laboratory, Faculty of Pharmacy, Jamia Hamdard, Hamdard Nagar, New Delhi 110062 , INDIA. \\ ${ }^{3}$ School of Pharmaceutical Sciences, IFTM University, Moradabad (U.P.), INDIA.
}

\begin{abstract}
Background: Abies webbiana commonly known as Talispatra in Bengali and Hindi, Talispatram in Sanskrit and Indian Silver Fir in English. This is a large, tall, evergreen tree occurring in the Himalayan region from Kashmir to Assam in India. It comes under the Family: Pinaceae. The present study was designed for isolation of flavonoid from ethyl acetate extract of A. webbiana leaves and assessed their toxic effect on liver and kidney. Materials and Methods: The isolation of flavonoid using different chromatographic methods (thin layer and column chromatography). The isolated flavonoid was identified; Structures and chemical bonds were analyzed by using MP, FTIR, 1-H NMR and MS spectral analysis. Effect of flavonoid on liver and kidney was assessed by inducing $(0.1 \mathrm{ml} / \mathrm{kg}) \mathrm{CCl}_{4}$ (i.p.) and $(6 \mathrm{mg} / \mathrm{kg})$ Cisplatin (i.p.) respectively measured by biochemical marker of liver and kidney. Results and Discussion: It was identified that isolated compound
\end{abstract}

was as 4'-hydroxy quercetin on the basis of FTIR, 1-H NMR and MS spectral analysis. Isolated flavonoid reduced the increased biochemical marker (BM) of liver and kidney. The BM was increased by inducing $\mathrm{CCl}_{4}$ and Cisplatin respectively. Conclusion: Isolated compound was 4'-methoxy quercetin and significantly protect the liver and kidney.

Keywords: Abies webbiana, Quercetin, 1-H NMR, Cisplatin, $\mathrm{CCl}_{4}$.

Corresponding author: Mr. Dinesh Kumar Yadav, College of Pharmacy, Shree Ganpati Institute of Technology, Opp- Jindal Pipes Ltd., NH-24 Ghaziabad, Uttar Pradesh, INDIA

Phone no: 8765918721

Email: dineshnbri08@gmail.com

DOI : 10.5530/pj.2016.4.6

\section{INTRODUCTION}

Abies webbiana commonly known as Talispatra in Bengali and Hindi, Talispatram in Sanskrit and Indian Silver Fir in English, is a large, tall, evergreen tree occurring in the Himalayan region from Kashmir to Assam in India. It comes under the Family: Pinaceae. ${ }^{1}$ The leaves of this plant have different uses in Ayurveda, ${ }^{2}$ the traditional system of Indian medicine and have been described for using against swasa, kasa, amadosha, hikka, chhardi and mukharoga. ${ }^{3}$ A. webbiana leaves has been reported as antibacterial and antifungal, mast cell stabilizing, anxiolytic, anti-tumor, anti-inflammatory, anti-tussive, female antifertility, febrifuge, anti-spasmodic properties, Central nervous system (CNS) depressant actions and are effective against hyperglycemia, conception, rheumatism and high temperature. ${ }^{2,4-8}$ In phytochemical screening certain chemical constituents, mainly monoterpenes (from essential oil), flavonoids, biflavonoid glycosides, phytosterols, amino acids, saponins, tannins, alkaloids, lipids, triterpenoids, steroids and glycosides were found and a new alkaloid namely 1-(4'-methoxyphenyl)-aziridine, a nitrogenous compound and a new biflavonoid, Abiesin have been isolated. ${ }^{9-13}$ The present study focuses on the isolation and assess effect on liver and kidney of flavonoid from ethyl acetate extract of A. webbiana. 4'-methoxy quercetin have been isolated from A. webbiana. Their structures have been elucidated through UV, FTIR, MS and 1-H NMR.

\section{MATERIALS AND METHODS}

\section{Collection of plant material}

The leaves of $A$. webbiana were collected from the forest of Tungnath (Garhwal, Utarakhand). Plant material was authenticated by Head, Department of Pharmacognosy and Ethno-Pharmacology, NBRI, Lucknow. The voucher specimen was preserved for the future reference. The leaves were separated from the branches and dried at the temp of $40^{\circ} \mathrm{C}$ for one hour before pulverization by mechanically grinder. The powder was passed through 40 mesh sieve and preserved for future purpose in tightly sealed container.

\section{Extraction}

800 gm of dried, coarsely powdered of leaves of $A$. webbiana was extracted with $99 \%$ ethanol using soxhlet apparatus. The extract was filtered and the solvent recovered by distillation. The filtered extract was evaporated under vacuum to give semisolid mass $(20 \% \mathrm{w} / \mathrm{w})$ which further dried. Alcoholic extract was suspended in small portion of water, extracted with ethyl acetate and then resulting solution were concentrated to provide ethyl acetate soluble parts. TLC finger prints and phytochemical tests were performed.

\section{Isolation of flavonoid ${ }^{15,16}$}

Ethyl acetate extract was loaded on silica gel (60-120 mesh) column chromatography for the isolation of phytoconstituent gave the various fractions, out of these five fraction no (16-20) from column chromatography were collected. These fractions have the same $R_{f}$ value when TLC was performed. Fractions were combined based on TLC analysis (developed in Toluene Ethyl acetate Formic acid (6:2:0.8). detected by ferric chloride solution and performed for flavonoid test (Alkaline test, Shinoda test and $\mathrm{ZN}-\mathrm{HCl}$ ). Concentrated fraction kept in refrigerator overnight for crystallization and melting point was measured.

\section{Experimental}

UV spectrum was measured with UV/Visible spectrophotometer (UV-1800 Shimadzu, Japan) in $\mathrm{C}_{2} \mathrm{H}_{5} \mathrm{OH}$ at room temperature. TLC was performed on a $0.25 \mathrm{~mm}$ thick Silica gel G (CDH, New Delhi). The TLC was detected by their UV fluorescence and by spraying with $0.5 \% \mathrm{FeCl}_{3}$. Column chromatography was performed with Silica gel 60-120 mesh (CDH, New Delhi). Melting points were determined on open capillaries using a Cintex melting point apparatus. IR Spectra were recorded on Perkin-Elmer spectrum BX series FTIR spectrometer. 1H-NMR spectrum was recorded on Bruker $500 \mathrm{MHz}$ spectrometers using TMS as internal standard. The chemical shifts are reported in ppm $(\delta)$ and coupling constants (J) are in Hz. Mass spectra was recordeded on Bruker $75 \mathrm{MHz}$ spectrometer. 


\section{Identification of flavonoid: $\mathbf{4}^{\prime}$ - methoxy quercetin ${ }^{14,17}$}

Yellow coloured solid compound was obtained and having m.p. $304^{\circ} \mathrm{C}$, $\mathrm{R}_{\mathrm{f}}$ value (Toluene Ethyl acetate Formic acid, 6:2:0.8) at 0.38, UV-Vis $\lambda_{\max }$ in Ethanol: (nm) 359, IR (KBr), m=862 (C-H, Ar), $1091(\mathrm{C}=\mathrm{O})$, 1129(-C-C-), 1165, 1259(-C-O- stretching) 1356, 1454 (C=O), 1515 (C,C, Ar), 1678, 1645 (C=C stretching) and 3416, 3360, 3251 (Ar-OH). 1HNMR(DMSO-d6), $\mathrm{d}=\delta 7.67(1 \mathrm{H}, \mathrm{d}, \mathrm{J}=1.8 \mathrm{~Hz} \mathrm{H}-2$ '), $7.54(1 \mathrm{H}, \mathrm{dd}$, $\mathrm{J}=1.8,8.4 \mathrm{~Hz} \mathrm{H}-6$ ') $6.88(1 \mathrm{H}, \mathrm{d}, \mathrm{J}=8.4 \mathrm{~Hz} \mathrm{H}-5$ '), 6.4(1 H, d, J=1.6 Hz H-8), 6.18( $1 \mathrm{H}, \mathrm{d}, \mathrm{J}=1.6 \mathrm{~Hz} \mathrm{H}-6), 3.33(3 \mathrm{H}$, brs, Ome), 4'-methoxy quercetin.

\section{Activity of flavonoid on Liver and Kidney \\ Animals}

Albino rats (Wistar) weighing 150-200 g of either sex were used in the present study. The animals were acclimatized for one week under laboratory conditions in SGIT, Ghaziabad (U.P.). They were housed in polypropylene cages and maintained at $22^{\circ} \mathrm{C} \pm 2{ }^{\circ} \mathrm{C}$ under $12 \mathrm{hrs}$ dark/ light cycle. They were fed with standard rat feed and water ad libitum. The experimental protocol was approved by the Institutional animals ethical committee (IAEC, Registration No SGIT/2014/04) prior to the beginning of the work.

\section{Acute toxicity study 18}

Flavonoid doses $(0.5,5,300,500 \mathrm{mg} / \mathrm{kg}$, p.o.) were used for acute toxicity in accordance to Organization for Economic Cooperation Development (OECD, 2002) guideline 423. Three rats, each sequentially dosed at intervals of $48 \mathrm{hrs}$, were used for the test. Once daily cage side observations included changes in skin, fur, eyes, mucous membrane (nasal), autonomic (salivation, lacrimation, perspiration, piloerection, urinary incontinence and defecation) and central nervous system (drowsiness, gait, tremors and convulsions) changes. Mortality, if any, was determined over a period of 2 weeks and dose was taken for isolated flavonoid (50 mg/kg, p.o.).

\section{Method for Evaluation of Hepatotoxicity activity 19-23}

In the dose response experiment, Wistar albino rats were taken randomly assigned into 3 groups of 6 individuals each. Group-I (-ve control) were administered $1 \mathrm{ml}$ distill water p.o., Group-II (+ve control) were administered $(0.1 \mathrm{ml} / \mathrm{kg}) \mathrm{CCl}_{4}$ (i.p.) and Group-III were administered $\left(\mathrm{CCl}_{4+} 50 \mathrm{mg} / \mathrm{kg}\right)$ isolated flavonoid p.o., for 5 days. Animals were sacrificed on the $6^{\text {th }}$ day under mild ether anesthesia. Blood samples were collected for evaluating the serum biochemical parameters such as Serum glutamate pyruvate transaminase (SGPT), Serum glutamate oxaloacetate transaminase (SGOT), Serum alkaline phosphates (SALP), Serum total bilirubin and Serum direct bilirubin were estimated by commercially available kits.

\section{Method for Evaluation of Nephrotoxicity activity24-26}

In the dose response experiment, albino rats were taken randomly assigned into three groups of 6 individuals each. Group-I (-ve control) were administered $1 \mathrm{ml}$ distill water p.o., Group-II (+ve control) were administered (6 mg/kg, i.p.) Cisplatin and Group-III Animals were administered (Cisplatin $+50 \mathrm{mg} / \mathrm{kg}$ ) isolated flavonoid p.o., for 7 days. The body weight of all the animals was taken on every day. The animals were sacrificed on day 7 under mild ether anesthesia. Kidney blood samples were collected and kidneys were weighed. The blood samples were used to measure serum creatinine and Blood urea nitrogen (BUN).

\section{Statistical Analysis}

The values were expressed as Mean \pm SEM. Statistical analysis was performed by tukey multiple comparison test One way analysis of variance (ANOVA) by Tukey multiple comparison test, was carried out and $\mathrm{p}<0.05$ was considered as significant $\mathrm{P}<0.01$ represent more significant and ${ }^{* * *} \mathrm{P}<0.001$ represent highly significant. Groups were compared with positive control and negative control group.

\section{RESULTS AND DISCUSSION}

Yellow coloured solid compound which was having sharp melting point m.p. $304^{\circ} \mathrm{C}$ that revealed its purity and in TLC single spot with value at $\mathrm{R}_{\mathrm{f}}=0.38$ was obtained. UV $\lambda_{\max }$ in Ethanol: $(\mathrm{nm})$ was obtained $359 \mathrm{~nm}$, IR $(\mathrm{KBr}), \mathrm{m}=862(\mathrm{C}-\mathrm{H}, \mathrm{Ar})$ showed aromatic carbon stretching, 1091 $(\mathrm{C}=\mathrm{O})$ showed presence of carbon oxygen, $1129(-\mathrm{C}-\mathrm{C}-)$ carbon stretching, 1165, 1259(-C-O-stretching) 1356, 1454 (C=O), 1515 (C,C, Ar), 1678, $1645(\mathrm{C}=\mathrm{C}$ stretching) and 3416, 3360, 3251 and was showing presence of hydroxyl aromatic (Ar-OH) (Figure 1).1-HNMR (DMSO-d6) (Figure 2) spectrum the presence of the H-2' was provided by the presence of one signal doublet at $\mathrm{d} 7.67 \mathrm{ppm} \mathrm{J}=1.8 \mathrm{~Hz}$ representing, signal as doublet at d $7.54 \mathrm{ppm} \mathrm{J}=1.8 \mathrm{~Hz}$ representing $\mathrm{H}-6$ ', presence of $\mathrm{H}-5$ ' was provided by one signal doublet at $\mathrm{d} 6.88 \mathrm{ppm} \mathrm{J}=8.4$, presence of $\mathrm{H}-8$ was provided by the presence of one signal doublet at $\mathrm{d} 6.4 \mathrm{ppm} \mathrm{J}=1.6 \mathrm{~Hz}$ representing, presence of $\mathrm{H}-6$ was provided by one signal doublet at $\mathrm{d} 6.18 \mathrm{ppm} \mathrm{J}=1.6$ $\mathrm{Hz}$ representing and $\mathrm{H}-3$ and methoxy was provided by the presence d 3.33 ppm. Molecular formula was found by $\mathrm{MS} \mathrm{C}_{16} \mathrm{H}_{12} \mathrm{O}_{7}(1-2)$ and $316[\mathrm{M}]^{+}$and isolated falvonoid was found as 4'-methoxy quercetin and their structure (Figure 3 ). ${ }^{14,17}$ No toxicity effects were found by acute toxicity studies but the higher dose of flavonoid has increased respiration of rats and lower dose was safe. Assessment for activity, one dose level were chosen in such a way that, high dose was approximately one-tenth of the maximum dose during acute toxicity studies, which was (50 mg/kg, p.o.). Preliminary phytochemical investigation of extract led to the presence of alkaloid, flavonoid, terpenoids, tannins, phenolic compound and glycosides. Hepatotoxicity study was performed and level of SGOT, SGPT, SALP and total bilurubin (Total and Direct) was (Showed in Table 1). It was found that the biochemical measurement were significant increased as compared to control (Group I) after administration of $\mathrm{CCl}_{4}$ (Group II). Isolated flavonoid (Group III) significant decreased the increased level of biochemical parameter as compare to negative control (Group II). Nephrotoxicity study was assessed and level of serum BUN, serum creatinine and serum protein and \% change of body weight shown in (Table 2). The levels of serum BUN, serum creatinine and serum protein and \% change of body weights were increased significantly in cisplatin treated animals (Group II) when compared to normal control animals (Group I). The extent of elevation was reduced significantly in animals which received isolated flavonoid (Group III). Exposure of $\mathrm{CCL}_{4}$ has been reported that free radical generated in tissue such as liver heart, brain, blood and testis. ${ }^{27}$ Free radical of $\mathrm{CCL}_{4}$ is believed to process leading the oxidative stress which is indirect cause the many pathological condition such as diabetes, cancer; liver damage and kidney damage. Most protein found in the plasma are synthesized by the hepatocytes and secreted in circulation. Reduction in total protein level at administration of $\mathrm{CCl} 4 .{ }^{21}$ Cisplatin significantly elevated the levels of serum BUN, serum creatinine and serum protein; and body weight. Cisplatin induces oxidative stress causing damage to intracellular organelles and alters this functions which lead to inhibition of protein synthesis glutathione depletion lipids peroxidation and mitochondrial damage. ${ }^{28}$ Flavonoids are a group of polyphenolic compounds which are present widely in plant kingdom both in the free state as glycosides and posses wide biological activities. The capability to interact with protein phosphorylation and the antioxidant iron chelating and free radicals scavenging activity. ${ }^{29,30}$ A number of flavonoids are known to possess good anti-inflammatory antibacterial, antiheptootxic activity. ${ }^{31}$ Flavonoids has reported that protective against environmental toxic agents and phytochemical analysis revealed that various chemical constituents like; monoterpenes (from essential oil), flavonoids, biflavonoid glycosides, phytosterols, amino acids, saponins, tannins, alkaloids, lipids, triterpenoids, steroids, diterpene glycosides and alkaloids are present in the leaf of A. webbiana. In the present investgation it was observed that pretreatment 
Table 1: Effect of isolated flavonoid from A. webbiana on liver biomarkers

\begin{tabular}{|c|c|c|c|c|c|}
\hline \multirow[t]{3}{*}{ Group } & \multicolumn{5}{|c|}{ Level of Biochemical Parameters } \\
\hline & \multirow{2}{*}{ SGOT (units) } & \multirow{2}{*}{ SGPT (units) } & \multirow{2}{*}{ SALP (units) } & \multicolumn{2}{|c|}{ Serum Bilurubin (units) } \\
\hline & & & & Total & Direct \\
\hline Control & $36.4 \pm 1.92$ & $43.66 \pm 1.83$ & $111.66 \pm 4.32$ & $0.35 \pm .023$ & $0.156 \pm 0.20$ \\
\hline $\mathrm{CCl}_{4}$ & $84 \pm 2.60^{a \star * *}$ & $86.33 \pm 1.21^{a \star * *}$ & $212.5 \pm 2.88^{\mathrm{a} * \star *}$ & $0.86 \pm 0.33^{\mathrm{a} \star \star}$ & $1.285 \pm 0.05^{\mathrm{a} \star *}$ \\
\hline $\begin{array}{l}\text { Isolated Flavonoid } \\
(50 \mathrm{mg} / \mathrm{kg})+\mathrm{CCl}_{4}\end{array}$ & $39.5 \pm 2.88^{* * *}$ & $54.66 \pm 3.14^{\star * *}$ & $100.66 \pm 3.07^{* * *}$ & $0.498 \pm 0.01^{\star *}$ & $0.133 \pm 0.02^{\star * *}$ \\
\hline
\end{tabular}

Values are mean \pm SEM $(\mathrm{N}=6)$ one way ANNOVA followed by Tukey's multiple comparison column test. Where ${ }^{\star}$ represent ${ }^{*} \mathrm{P}<0.05$ represent significant, ${ }^{* *} \mathrm{P}<0.01$ represent more significant and ${ }^{* * *} \mathrm{P}<0.001$ represent highly significant compare with $\mathrm{CCl}_{4}$ group and ${ }^{\mathrm{a}^{*}}$ represent significant compare with Control group.

Table 2: Effect of isolated flavonoid from $A$. webbiana on Nephrotoxicity

\begin{tabular}{ccccc}
\hline \multirow{2}{*}{ Group } & \multicolumn{3}{c}{ LEVEL OF BIOCHEMICAL PARAMETERS } \\
\cline { 2 - 5 } & $\begin{array}{c}\text { \% change in } \\
\text { body weight }\end{array}$ & $\begin{array}{c}\text { Serum creatinine } \\
(\mathrm{mg} / \mathrm{dl})\end{array}$ & $\begin{array}{c}\text { Serum BUN } \\
(\mathrm{mg} / \mathrm{dl})\end{array}$ & $\begin{array}{c}\text { Serum protein } \\
(\mathbf{g} / \mathrm{dl})\end{array}$ \\
\hline Control & $1.275 \pm 0.06$ & $0.781 \pm 0.01$ & $16.92 \pm 0.04$ & $3.887 \pm 0.09$ \\
Cisplatin & $13.55 \pm 0.95^{\text {a***}}$ & $2.079 \pm 0.01^{\text {a***}}$ & $26.87 \pm 0.06^{\text {a***}}$ & $9.491 \pm 0.25^{\text {a***}}$ \\
$\begin{array}{c}\text { Isolated Flavonoid } \\
(50 \mathrm{mg} / \mathrm{kg})+\text { Cisplatin }\end{array}$ & $1.78 \pm 0.075^{* * *}$ & $1.010 \pm 0.08^{* * *}$ & $22.01 \pm 0.06^{* * *}$ & $5.745 \pm 0.11^{* * *}$ \\
\hline
\end{tabular}

Values are mean \pm SEM $(\mathrm{N}=6)$ one way ANNOVA followed by Tukey's multiple comparison column test. Where * represent significant at $\mathrm{P}<0.05$, ${ }^{* *}$ represent more significant at $\mathrm{P}<0.01$ and ${ }^{* * *}$ represent highly significant compare with Cisplatin group and ${ }^{{ }^{*}}$ represent significant compare with Control group.

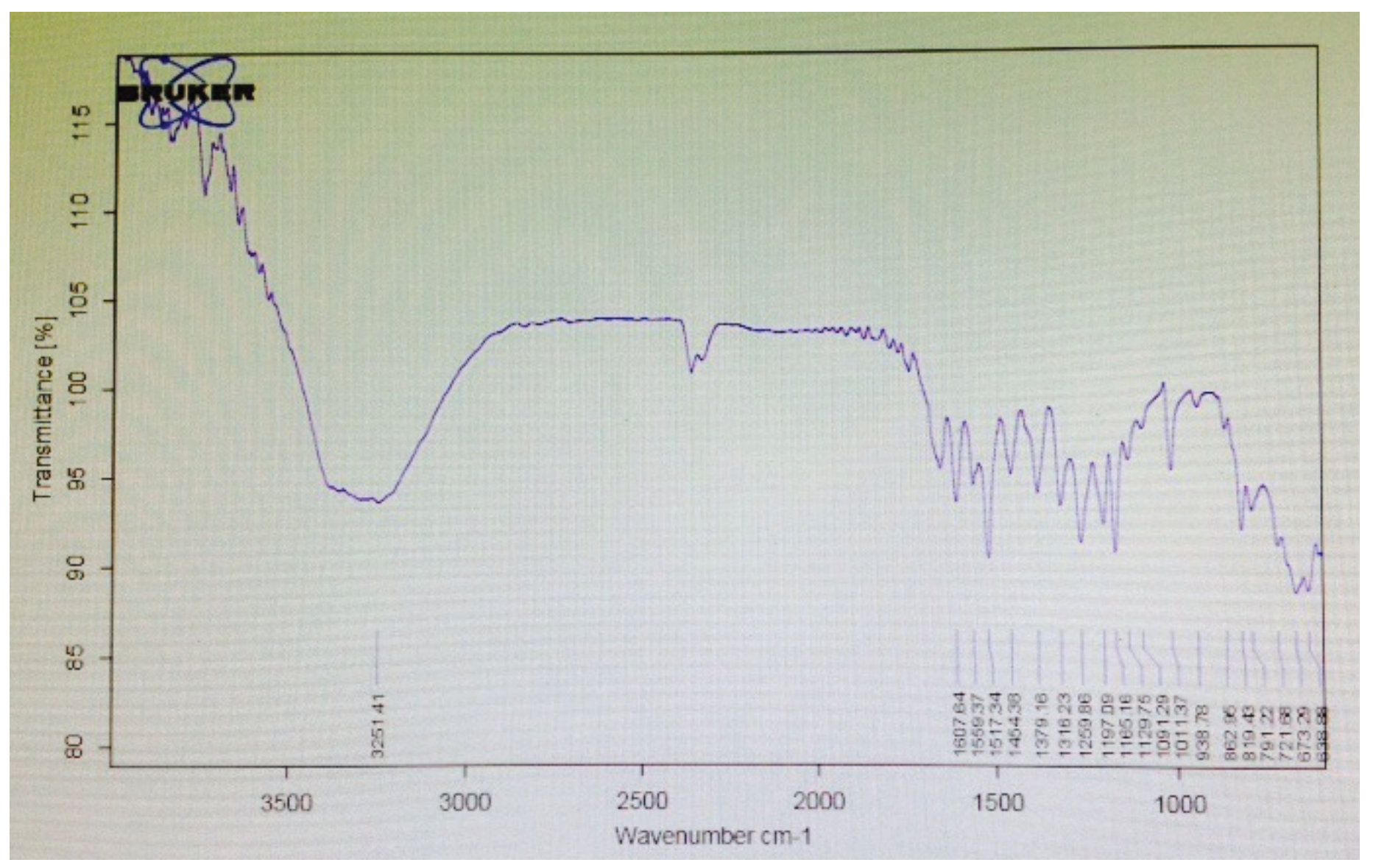

Figure 1: FTIR spectra of flavonoids. 
DMSO

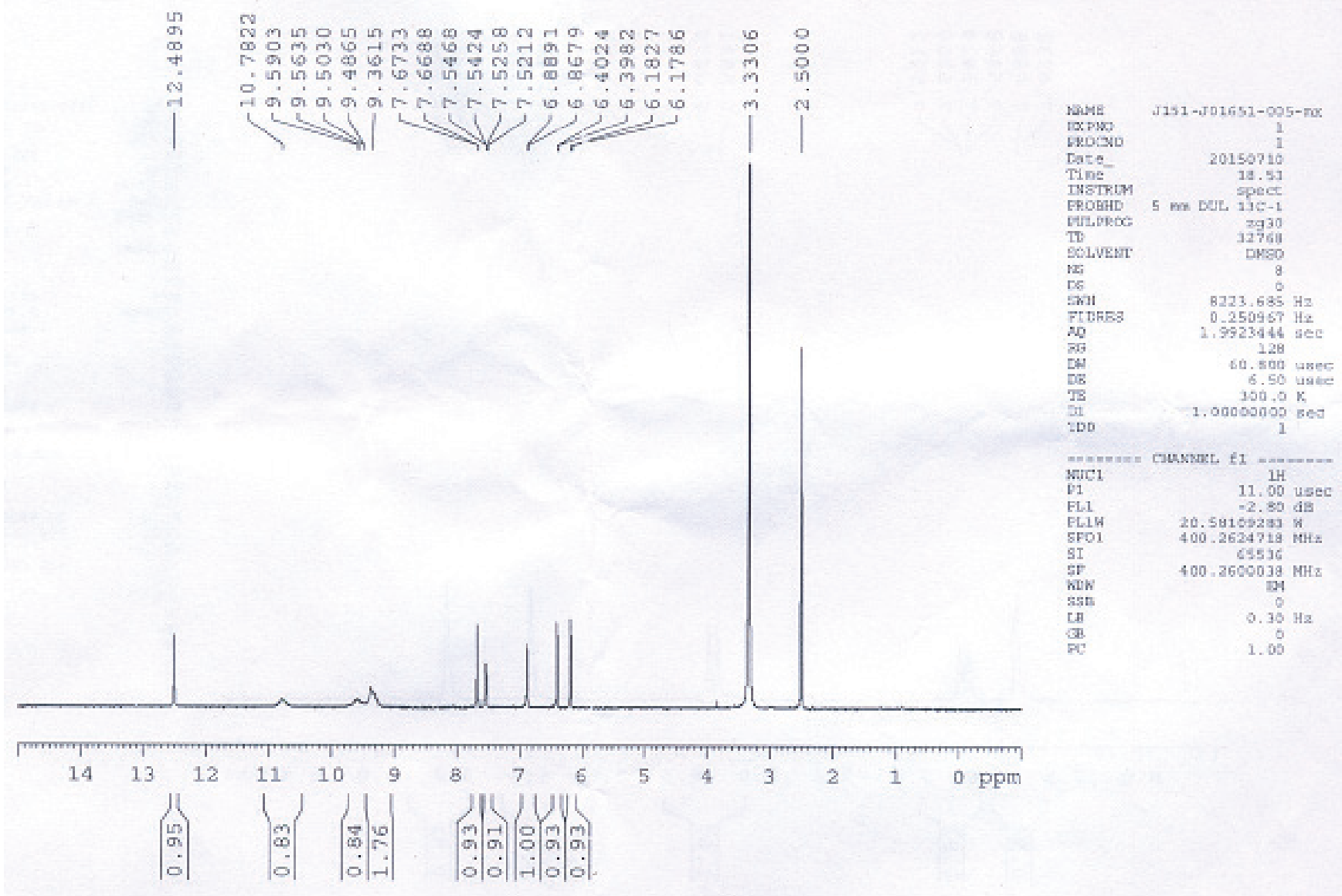

Figure 2: The 1H-NMR spectra of flavonoid.<smiles>COc1ccc(-c2oc3cc(O)cc(O)c3c(=O)c2O)cc1O</smiles>

Figure 3: Isolated flavonoids.

flavonoid ( $50 \mathrm{mg} / \mathrm{kg}$ p.o.) for 5 days has significantly reduced the elevated biochemical markers of liver and kidney.

\section{CONCLUSION}

It may be concluded that flavonoid has isolated successfully from the A. webbiana leaves and on the basis of spectral data; the compounds were identified as 4'-methoxy quercetin. It was found that no toxic effect of flavonoid on liver and kidney, instead of whereas it shows protective effect on liver and kidney strongly.

\section{ACKNOWLEDGEMENT}

The authors are grateful to Dr. A.K.S Rawat, Head, Department of Pharmacognosy and Ethno-Pharmacology, NBRI, Lucknow (U.P.) for plant identification and authentication. Authors are also grateful to Mr. Vivek Yadav, Research associate, Jubliant chemsys Ltd, Noida, Ghaziabad for spctroscopical analysis.

\section{CONFLICT OF INTEREST}

All authors have no conflict of interest.

\section{ABBREVIATION USED}

MP: Melting point; FTIR: Fourier transform infrared; 1-H NMR: Hydrogen Nuclear magnetic resonance; MS: Mass spectroscopy; UV: Ultraviolet-visible; TLC: Thin layer chromatography; ZN- HCl: Zinc hydrochloride; TMS: Tetramethysilane; $\mathbf{M H z}$ : Megahertz, $\mathbf{R}_{\mathrm{f}}$ : Retention Factors; OECD: Organization for Economic Cooperation and Development; $\mathbf{C C l}_{4}$ : Carbon tetrachloride; $\mathbf{B M}$ : Bio- marker; SGPT: Serum glutamate pyruvate transaminase; SGOT: Serum glutamate oxaloacetate transaminase; SALP: Serum alkaline phosphates; BUN: Blood Urea Nitrogen; i.p: Intraperitoneal.

\section{REFERENCES}

1. Chatterjee A, Kotoky J, Das KK, Banerji J, Chakraborty T. Abiesin, a biflavonoid of Abies webbiana. Phytochemistry. 1984;23(3):704. 
2. Sarkar SK, Poddar G, Mahato SB. Glucoside from Abies webbiana. Planta Medica. $1986 ; 4(2): 219$.

3. Rawat AKS, Mehrotra S, Shome U. Comparative pharmacognostical studies on the leaves of Abies spectabilis and Taxus wallichiana. International Journal of Pharmacognosy. 1996;34(5):378.

4. Nayak SS, Ghosh AK, Debnath B, Jha T. Anti tussive activity of A. webbiana Lindl. Leaf extract against sulphur dioxide-induced cough reflex in mice. Phytotherapy Research. 2003;17(8):930.

5. Nayak SS, Ghosh AK, Debnath B, Vishnoi SP, Zaman TJ. Synergistic effect of methanol extract of Abies webbiana leaves on sleeping time induced by standard sedatives in mice and Anti-inflammatory activity of extracts in rats. J Ethnopharmacol. 2004;93(2):397.

6. Kumar VPN, Chauhan S, Padh H, Rajani M. Search for antibacterial and antifungal agents from selected Indian medicinal plants. J Ethnopharmacol. 2006; 107(2):182.

7. Visnoi SP, Basu A, Alam SKM, Samanta S, Jha T. Evaluation of the antipyretic potential of methanol extract of the leaves of Abies spectabilis(D. Don) Spach. Natural product of Radiance. 2007;6(5):369.

8. Visnoi SP, Ghosh AK, Debnath B, Samanta S, Gayen S, Tha T. Antibacterial activity of Abies webbiana. Fitoterapia. 2007;78(2):153.

9. Ghosh AK, Bhattacharya S. Pharmacognostic Studies on Leaves of Abies webbiana Grown in Sikkim Himalayan Region of India. Pharmacognosy Journal. 2009;1(2):171.

10. Ghosh AK, Bhattacharya S. Planar chromatographic studies on Abies webbiana leaves. International Journal of Chem Tech Research. 2009;1(4):807.

11. Ghosh AK, Sen D, Bhattacharya S. A nitrogenous compound isolated from Abies webbiana leaf. Der Pharma Chemical. 2010;2(3):205.

12. Ghosh AK, Sen D, Bhattacharya S. A new alkaloid isolated from Abies webbiana Leaf. Pharmaognosy Research. 2010;2(3):186.

13. Nadkarni AK. Indian material medica, Bombay Popular Prakashan, 1976: $1^{\text {st }}$ ed.3.

14. Selvaraj K, Chowdhury C, Bhattacharjee C. Isolation and structural elucidation of flavonoids from aquatic fern azolla microphylla and evaluation of free radical scavenging activity. Int J Pharm Pharm Sci. 2013;5(3):743-9.

15. Harbone JB. Phytochemical methods. A Guide to modern techniques of plant analysis,. Chapmann and Hall, London, 1973:1 ${ }^{\text {st }}$ ed. 29.

16. Kokate CK, Purohit AP, Gokhale SB. Pharmacognosy, Nirali Prakashan, 2004:

17. Adil A, Mujwah A, Mohammed A, Mohammed B, Mohammed $\mathrm{H}$, Ahmed C. First isolation of a flavonoid from Juniperus procera using ethyl acetate extract.
Arabian Journal of Chemistry. 2010;3(2):85-8.

18. OECD, Guideline for testing of chemicals, Acute oral toxicity, Environmental Health and Safety monograph series on testing and adjustment No 423, 2002:1.

19. Zeeyaudin K, Setty RCS, Majid MSA, Ibrahim M. Evaluation of hepatoprotective activity of Boswellia serrata leaves extracts in albino rats. Indian Drugs. 2010;47(2):14.

20. Kumar SVS, Mishra SH. Hepatoprotective activity of rhizomes of Cyperus rotundus Linn against carbon tetrachloride-induced hepatoxicity. Indian J of Pharm Sci. 2005;67(1):84.

21. Girish C, Koner BCS, Jayanthi KR, Rao B, Pradhan RSC. Hepatoprotective activity of six polyherbal formulations in paracetamol induced liver toxicity in mice. Indian J Med Res. 2009:129(5):569.

22. Sharstry RA, Biradar SM, Mahadevan KM, Habbu PV. Isolation and characterization of secondary metabolite from Amorphophallus paeoniifolius for Hepatoprotective activity. Research J Pharm Bio and Chem Sci. 2010;1(4):429.

23. Suja SR, Latha PG, Pushpangadan P, Rajasekharan S. Evaluation of hepatoprotective effects of Helminthostachyes zeylanica (L.) hook against carbon tetrachloride induced liver damage in Wister rats. J Ethnopharmacol. 2004;92(1):61.

24. Sreedevi KB, Prasad KVSRG. Protective effect of rutin against cisplatin-induced nephrotoxicity in rats. Journal of Natural Remedies. 2010;10(2):144.

25. Corcostegui R, Labeaga L, Arteche JK, Orjales A. Protective effect of hidrosmin against cisplatin induced acute nephrotoxicity in rats. J Pharm Pharmacol. 1998;4(9):465

26. Devi PS, Shaymal DCS. Protective effect of quercetin in cisplatin-induced cell injury in the rat kidney. Indian J Pharmacol. 1999;31(6):422.

27. Chioma AA, Uchenna BU, Ogechi N. Effect of ethanol extract of Pyrenacantha staudtii leaves on carbon tetrachloride induced hepatotoxicity in rats. Biochemistry. 2008;20(1):172

28. Kostova I. Platinum complex as anticancer agents, recent patents anticance drug Discover. 2006;1(1):1.

29. Saija A, Scales M, Lanza M, Marullo D, Bonina F. Flavonoids as antioxidant agents: Importance of their interaction with biomembranes. Free Rad Biol Med.1995;19(4):481.

30. Saija A, Tomario A, Trombetta D, Giacchi M, Pasquale AD, Bonina F. Influence of different penetration enhancers on in vitro skin permeation and in vivo photoprotective effect of flavonoids. Int J Pharm. 1998;175(1):85.

31. Trease, EWC. Pharmacognosy, Saunders company London, (W.B.).1996:249

\section{PICTORIAL ABSTRACT}

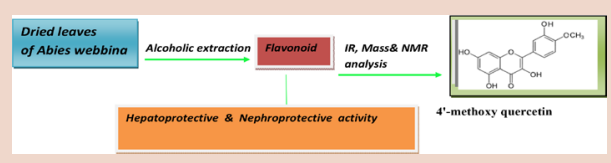

\section{SUMMARY}

- It may be concluded that flavonoid has isolated successfully from the A. webbiana leaves and on the basis of spectral data of Mass, IR and NMR; the compounds were identified as 4'-methoxy quercetin.

- Flavonoid is highly responsible for protection of liver and kidney.

- It was found that no toxic effect of flavonoid on liver and kidney, instead of whereas it shows protective effect on liver and kidney strongly.

\section{ABOUT AUTHOR}

Dinesh KumarYadav: Is an associate professor, college of pharmacy, SGIT, Ghiaziabad, U.P., India. His research field focuses on Phytochemistry and biological activity testing of natural products. 